\title{
Braga cigarra comb. nov. for Philostomella cigarra (Crustacea: Isopoda: Cymothoidae) with a redescription of the species based on specimens from Galeocharax kneri, a freshwater fish of Minas Gerais State, Brazil
}

\author{
Vernon E. Thatcher ${ }^{\text {; }}$ Antonio A. N. de Oliveira ${ }^{2} \&$ Adriana M. Garcia ${ }^{2}$ \\ ${ }^{1}$ Departamento de Zoologia, Universidade Federal do Paraná. Caixa Postal 19020, 81531-980 Curitiba, Paraná, Brasil. \\ E-mail: thatcher@ufpr.br \\ ${ }^{2}$ Departamento de Medicina Veterinária Preventiva, Universidade Federal de Lavras. Caixa postal 3037, 37200-000 Lavras, \\ Minas Gerais, Brasil. E-mail: toninhovet@yahoo.com.br; amgarcia@ufla.br
}

\begin{abstract}
Specimens of a cymothoid isopod from a freshwater fish of Minas Gerais State were studied. These were found to be morphologically comparable to Philostomella cigarra Szidat \& Schubart, 1960, except for having multilaminate pleopods which is the distinguishing characteristic of the genus Braga Schiödte \& Meinert, 1881. The first pleopod is bilaminate while the second is quadrilaminate. Pleopods three to five are trilaminate. It is herein proposed that the generic name Philostomella Szidat \& Schubart, 1960, should be considered invalid and that the species $P$. cigarra should be transferred to Braga. Braga now contains eight species, including B. cigarra comb. nov., all from South American freshwater fishes. The principal difference between this species and the others in the genus is the form of the female which has a narrow pleon and a small pleotelson. A redescription of this species is presented here because previous descriptions in the literature are inaccurate or incomplete.

KEY WORDS. Cymothoid; freshwater fish parasite; South America.
\end{abstract}

Braga was proposed by Schiödte \& Meinert (1881) to include Braga nasuta, B. cichlae and B. brasiliensis, isopod parasites of South American freshwater fishes. Later, the same authors added B. patagonica (see SchiöDte \& Meinert 1884). According to THATCHER (2006), the following species are also known from this genus: B. amapaensis Thatcher, 1996; B. bachmanni Stadler, 1972 and B. fluviatilis Richardson, 1911.

SZIDAT \& SCHUbart (1960) proposed Philostomella cigarra for a cymothoid parasite found in the mouth of Galeocharax humeralis (Valenciennes, 1834) in São Paulo State, Brazil. Taberner (1986) considered the genus and species valid and redescribed it. In the present study, we have been able to examine specimens of this species from Galeocharax kneri (Steindachner, 1879) of Minas Gerais State, Brazil. We propose that this species should be placed in Braga. It is necessary to redescribe the species because of omissions and misinterpretations in previous descriptions.

\section{MATERIAL AND METHODS}

Fish hosts, Galeocharax kneri (Steindachner, 1879), were netted in the Rio Grande, near Lavras, State of Minas Gerais, Brazil. They were taken on ice to the Department of Veterinary Medicine of the Universidade Federal de Lavras for examination. The isopod parasites were removed from the mouth of the hosts and fixed in 70\% ethanol. The preserved specimens were sent to the Department of Zoology of the Universidade Federal do Paraná, Curitiba, for detailed studies. There, dissec- tions of the mouthparts, pereopods, pleopods and uropods were examined after clearing in pure phenol to better visualize their morphology. Photographs were made with a digital camera which were used in making the drawings. Measurements are given in micrometers $(\mu \mathrm{m})$ except where designated as millimeters (mm).

\section{TAXONOMY}

Material examined. Six females and seven males collected by the second author from the mouth of Galeocharax kneri caught in the Rio Grande near Lavras, Minas Gerais State, Brazil. The females measured 18-27 (23) $\mathrm{mm}$ long by 8-12 (10) $\mathrm{mm}$ wide and the males 17-28 (23) mm long by 8-12 (10) mm wide.

\section{Braga Schiödte \& Meinert, 1881}

Diagnosis (from ThAтснек 2002). Female: body about twice as long as wide, symmetrical. Cephalon not immersed in pereonite 1; frons obtuse, truncate or acute; antennal bases well separated. Pereonite 1 two to three times the length of $7 ; 5$ and 6 shorter than 2-5; coxae compact, not extending posterior to respective pereonites. Pereopods relatively long with $7^{\text {th }}$ pair longer than others. Mandible subrectangular, lacking cutting process and incisor. Pleon slightly immersed in pereonite 7; pleonites usually produced laterally; pleopods multilaminate; 1 bilaminate, 2 quadrilaminate and 3-5 trilaminate. Pleotelson shield-like not keeled; uropods short with endopod shorter than exopod. 
Type species. Braga nasuta Schiödte \& Meinert, 1881.

Other species. Braga amapaensis Thatcher, 1996; B. bachmanni Stadler, 1972; B. brasiliensis Schiödte \& Meinert, 1981; $B$. cichlae Schiödte \& Meinert, 1881; B. fluviatilis Richardson, 1911; B. patagonica Schiödte \& Meinert, 1884.

Remarks. Although SchiöDte \& MeinerT (1881) described three species of Braga in the same paper and did not indicate which was the type, $B$. nasuta was mentioned and described first. Based on this observation, TriLles (1973) listed this species as type.

\section{Braga cigarra comb. nov.}

Figs 1-41

Braga cichlae; Lemos de Castro, 1959: 70, pls 1, 2, figs 1-19; 1981: 32. Not Braga cichlae Schiödte \& Meinert, 1881 (misidentification).
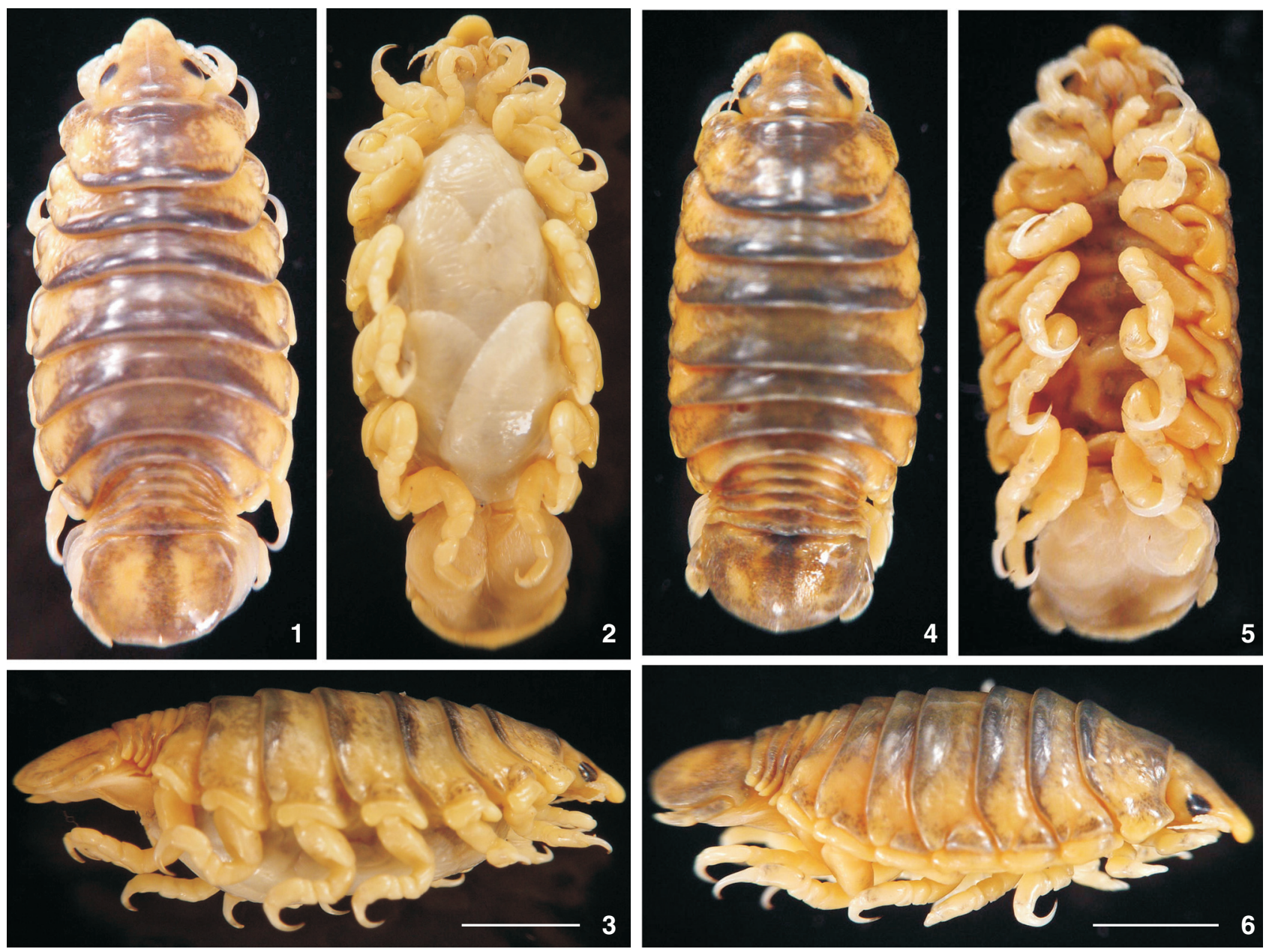

Figures 1-6. Braga cigarra comb. nov. (1-3) Female: (1) entire, dorsal; (2) entire, ventral; (3) entire, lateral. (4-6) Male: (4) entire, dorsal; (5) entire, ventral; (6) entire, lateral. Scale $=5 \mathrm{~mm}$.

ZOOLOGIA 26 (1): 155-160, March, 2009

Philostomella cigarra Szidat \& Schubart, 1960: 114, figs 8-13; Trilles, 1973: 248, pl. II, fig. 7; 1994: 205; Godoy, 1975: 239, figs 38-39; Thatcher, 1991: 510, figs 10-7 A-C and 10-49; 2000: 202, fig. 22; 2002: 108. fig. 176; 2006: 425, figs 10-24; Taberner, 1981: 2 .

Species description based on six females and seven males. Female (Figs 1-3): Body narrowly elongate, about 2.5 times longer than wide, widest at pereonites 4 and 5. Cephalon triangular, with frons produced, rounded and doubled downward. Antennule (Fig. 7) stout, shorter than antenna, of eight articles; antenna (Fig. 8) slender, of nine articles. Mouthparts: mandible foot-shaped, palp of three segments (Fig. 12); maxillule (Fig. 9) with five recurved spines, three terminal and two subterminal; maxilla (Fig. 11) bilobed, with one recurved spine on one lobe and two on the other; maxilliped (Fig. 10) with finger-like anterior projection bearing two stout hooks on its tip. Pereon

\section{.}




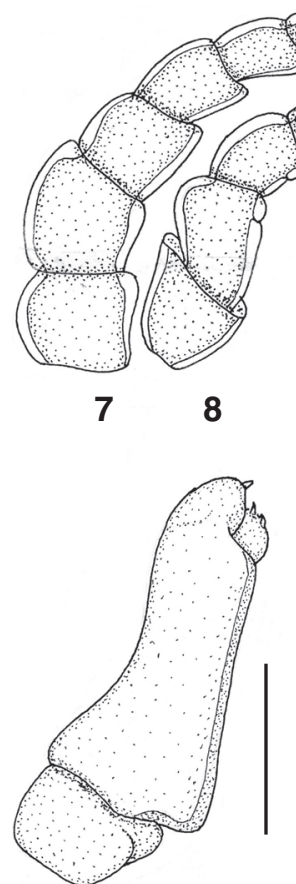

11

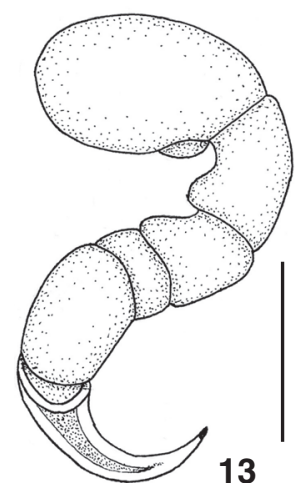

13

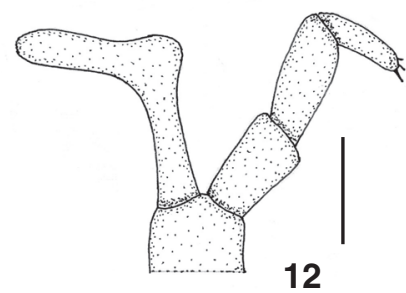

12
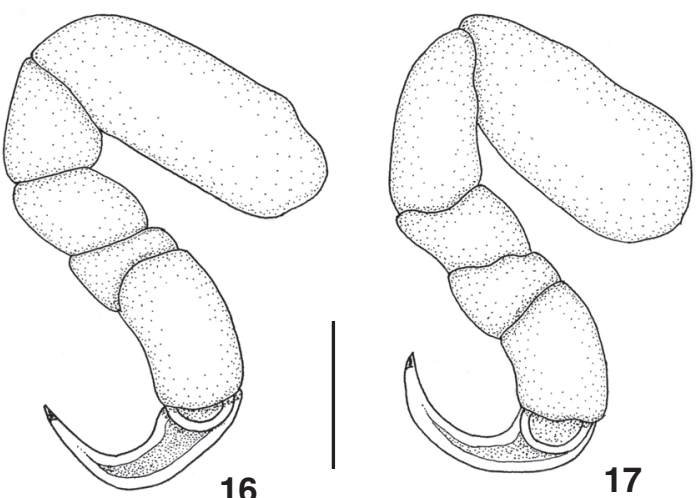

17
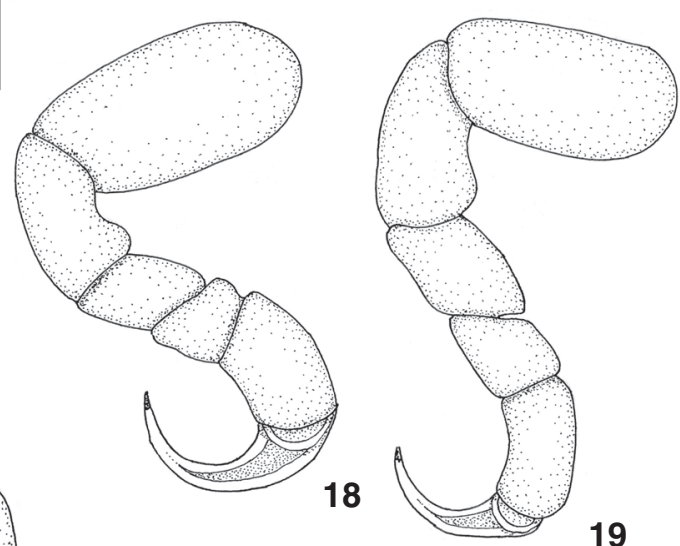

19

15

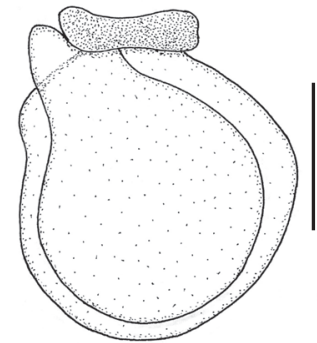

20
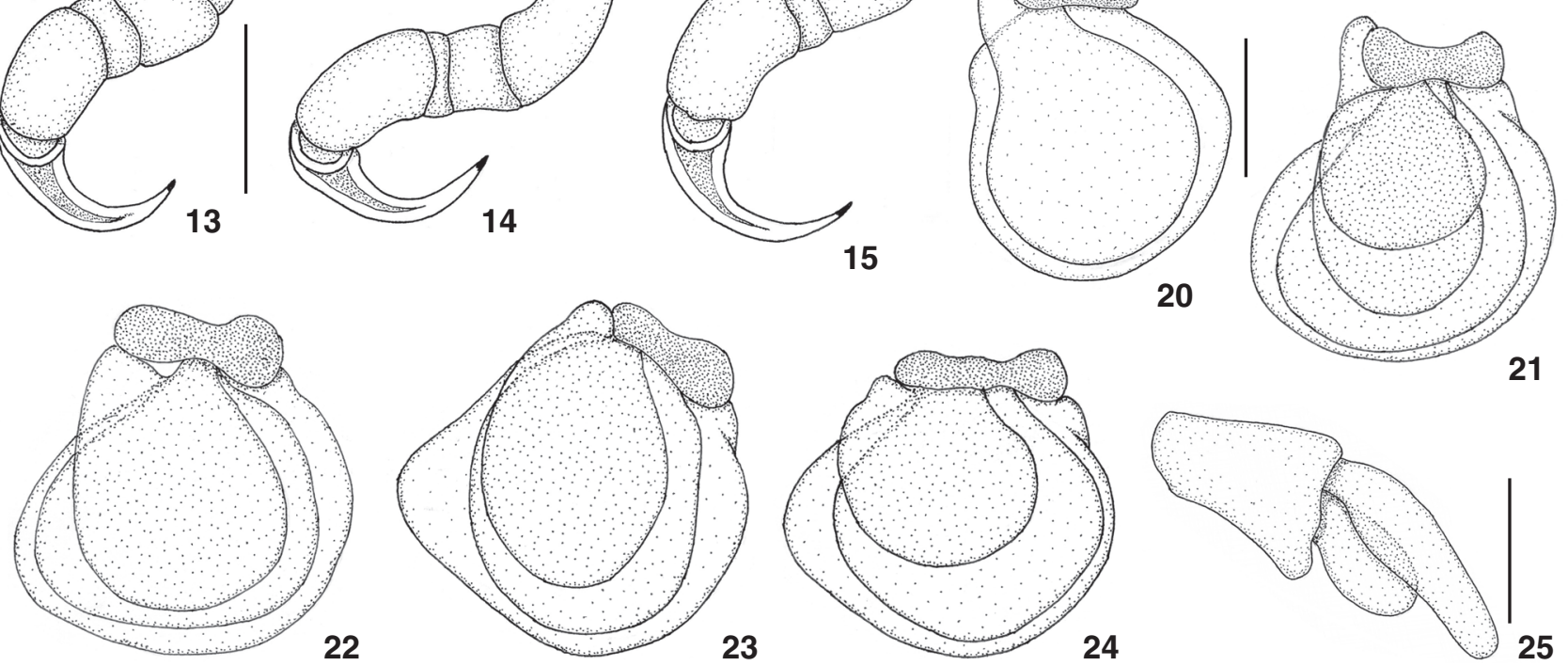

21

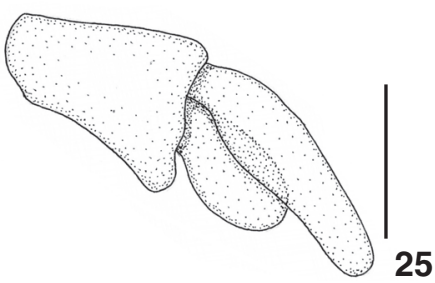

Figures 7-25. Braga cigarra comb. nov., female: (7) antennule; (8) antenna; (9) maxillule; (10) maxilliped; (11) maxilla; (12) mandible and palp; (13) pereopod 1; (14) pereopod 2; (15) pereopod 3; (16) pereopod 4; (17) pereopod 5; (18) pereopod 6; (19) pereopod 7; (20) pleopod 1; (21) pleopod 2; (22) pleopod 3; (23) pleopod 4; (24) pleopod 5; (25) uropod. Scales: 7-8 = $500 \mu \mathrm{m}, 9-10=100 \mu \mathrm{m}$, $11=1 \mathrm{~mm}, 12=50 \mu \mathrm{m}, 13-19=2 \mathrm{~mm}, 20-24=3 \mathrm{~mm}, 25=1 \mathrm{~mm}$. 


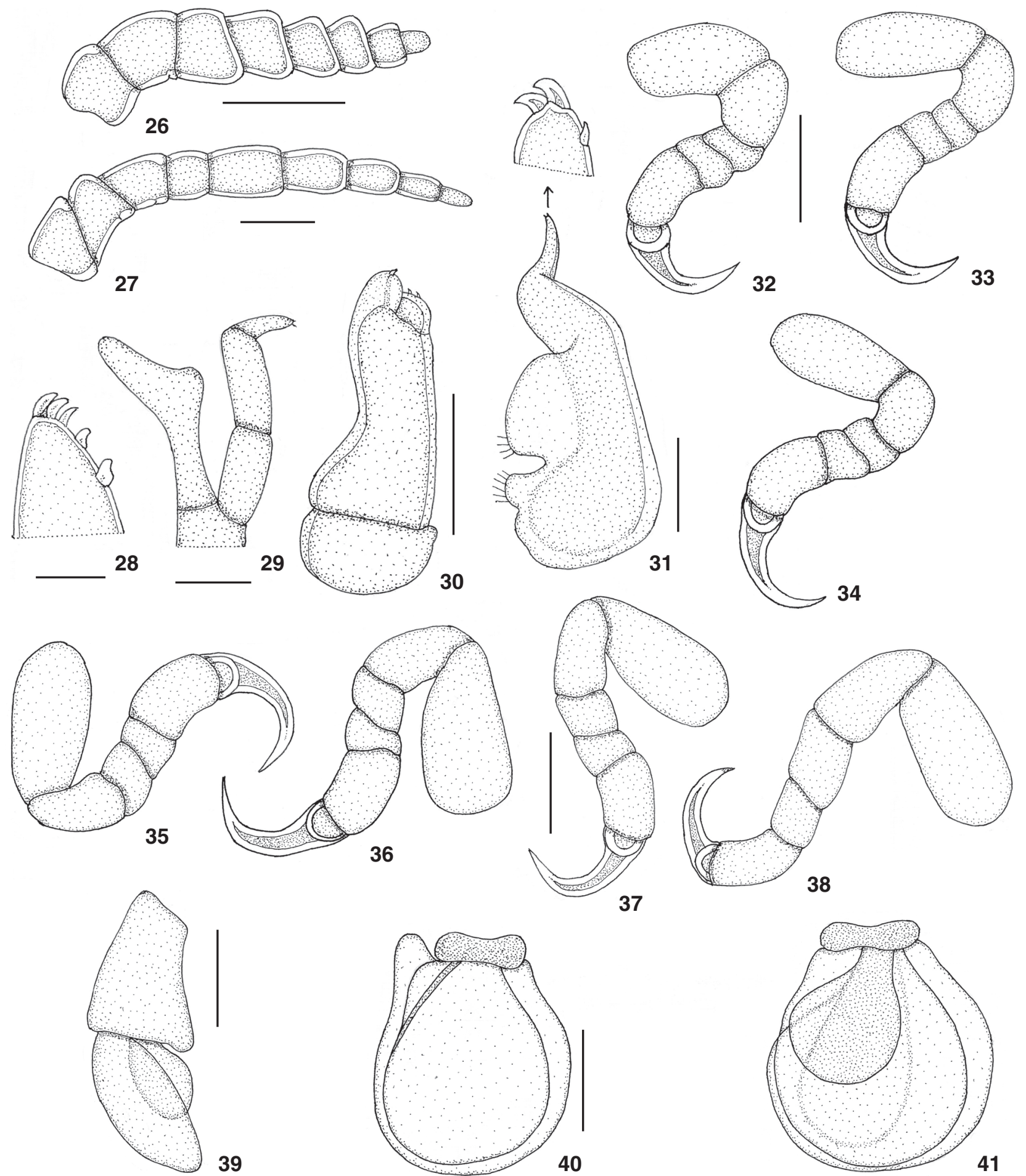

Figures 26-34. Braga cigarra comb. nov., male: (26) antennule; (27) antenna; (28) tip of maxillule; (29) mandible and palp; (30) maxilla; (31) maxilliped; (32) pereopod 1; (33) pereopod 2; (34) pereopod 3; (35) pereopod 4; (36) pereopod 5; (37) pereopod 6; (38) pereopod 7; (39) uropod; (40) pleopod 1; (41) pleopod 2. Scales: 26, 27, 30-31, $39=1 \mathrm{~mm} ; 28=100 \mu \mathrm{m} ; 29=50 \mu \mathrm{m} ; 32-38=2 \mathrm{~mm}$, $40-41=3 \mathrm{~mm}$. 
(Fig. 1) sides nearly parallel; pereonite 1 slightly longer than 2 and 3; pereonite 4 about as long as 1; 7 less than half the length of 4. Pereopods (Figs 13-19) all provided with stout claws. Pleon (Fig. 1) abruptly narrower than pereon; with lateral extensions of pleonites. Pleopods (Figs 20-24) multilaminate. Pleotelson wider than long; narrower than pleonite 7. Uropod (Fig. 25) with short, rounded endopod, slightly more than half the length of exopod; not reaching posterior margin of pleotelson.

Male (Figs 4-6). Body and cephalon similar to those of female. Antennule (Fig. 26) stout, shorter than antenna, with eight articles; antenna (Fig. 27) slender, with nine articles. Mouthparts: mandible foot-shaped, palp of three segments (Fig. 29); maxillule (Fig. 28) provided with five, small recurved spines, three terminal and two subterminal; maxilla (Fig. 30) bilobed, with one spine on one side and two on the other; maxilliped (Fig. 31) with finger-like anterior extension having two stout, terminal, recurved spines and one small subterminal spine. Pereon (Figs 23 and 25) laterally rounded; pereonites 1 and 4 longest; 7 shortest. Pereopods (Figs 32-38) 1-3 smaller than others; 7 longest; all provided with stout claws. Pleon (Fig. 23) narrower than pereon; pleonites with lateral extensions. Pleopods (Figs 40 and 41) multilaminate. Pleotelson wider than long. Uropod (Fig. 39) with short, rounded endopod; not reaching posterior extremity of pleotelson.

Hosts. Galeocharax kneri (Steindachner, 1879) and Galeocharax humeralis (Valenciennes, 1834).

Site. Mouth.

Geographic distribution. São Paulo State to Minas Gerais State, Brazil.

Voucher specimens. Five females and six males (in 70\% ethanol) deposited in the Crustacean Collection of the Instituto Nacional de Pesquisas da Amazônia, Manaus, Amazonas State. Access number INPA 1676.

\section{DISCUSSION}

SzIDAT \& Schubart (1960) described a cymothoid isopod from the mouth of a characid fish from the Mogi-Guassu River, near Pirassununga, state of São Paulo, Brazil. They believed that this cymothoid represented a new genus and they gave it the name Philostomella cigarra. Their new genus was based mainly on the body shape of the female which has a narrow pleon and a small pleotelson. Apparently, they did not examine the pleopods. Lemos DE CASTro (1981) listed this species as a synonym of Braga cichlae Schiödte \& Meinert, 1881, perhaps because the males resemble that species. TABERNER (1986) studied specimens from the same locality and from the same host fish, Galeocharax humeralis (Valenciennes, 1834). He reached the conclusion that Philostomella Szidat \& Schubart, 1960 should be considered valid since it had multilaminate pleopods which were unknown in other genera. Apparently, he did not examine the pleopods of any species of Braga.

THATCHer (1995) studied the pleopods of eleven species of parasitic isopods from Brazil and compared their morphol- ogy. The cymothoid genera examined were: Artystone Schiödte, 1886, Asotana Schiödte \& Meinert, 1881, Braga, Nerocila Leach, 1818, Riggia Szidat, 1948 and Telotha Schiödte \& Meinert, 1884. In Braga, the following nominal species were examined: $B$. cichlae, B. nasuta and B. patagonica. It was found that all species of Braga had multilaminate pleopods and that these structures in the other genera were all bilaminate. In Braga spp., only the first pleopod is bilaminate while the second is quadrilaminate and the third to the fifth are all trilaminate. It was therefore concluded that multilaminate pleopods are the determining character of Braga.

In the case of Philostomella, TABERNER (1986) affirmed that multilaminate pleopods should define the genus. He stated that the first was bilaminate and all the others trilaminate. We find that specimens of $P$. cigarra have multilaminate pleopods exactly comparable to those of species of Braga, including a quadrilaminate second pleopod. Since the latter genus was proposed first, it takes precedence over Philostomella. The species cigarra can be separated from the others in the genus on the basis of the narrow pleon and small pleotelson of the female. The species should therefore be considered valid and transferred to Braga.

Braga cigarra comb. nov. is apparently quite host specific. It was originally found in a freshwater fish known locally as "peixe cadela" in Southern Brazil. The scientific name of the host at that time was Cynopotamus humeralis Valenciennes, 1834. The name of the host has since been changed to Galeocharax humeralis (Valenciennes, 1834). Our material came from a related species, Galeocharax kneri (Steindachner, 1879) from Minas Gerais State, Brazil.

\section{ACKNOWLEDGMENTS}

This is the contribution number 1777 of the Departamento de Zoologia, Universidade Federal do Paraná.

\section{LITERATURE CITED}

Godoy, M.P. 1975. Peixes do Brasil. Piracicaba, Ed. Franciscana, vol. 2, 433p.

Lemos de Castro, A. 1981. Isopoda, p. 32-35. In: S.H. Hurlbert; G. Rodriguez \& N. Dos Santos (Eds). Aquatic Biota of Tropical South America. Part 1. Arthropoda. San Diego, San Diego State University, 307p.

SchiöDte, J.C. \& F. Meinert. 1881. Symbolae ad Monographiam Cymothoarum Crustaceorum Isopodum, Familie II. Anilocridae. Naturhist Tidsskrift, Serie 3, 13: 1-166.

SchiöDte, J.C. \& F. Meinert. 1884. Symbolae ad Monographiam Cymothoarum Crustaceorum Isopodum, Familie II. Anilocridae. Naturhist Tidsskrift, Serie 4, 14: 221-454.

Szidat, L. \& O. Schubart. 1960. Neue und seltene Parasitische Süsswasser Anselm der Familie Cymothoidae aus dem Rio Mogi-Guassú, Brasilien (Isopoda). Anais da Academia Brasileira de Ciência 32 (1): 107-124. 
TABerner, R. 1981. Isopoda, p. 1-4. In: S.H. Hurlbert (Ed.). Biota Acuática de Sudamerica Austral. Assenda and Corrections. San Diego, 437p.

TABerner, R. 1986. Redescripción y posición sistemática de Philostomella cigarra Szidat y Schubart, 1960 (Isopoda: Cymothoidae). Physis, Sección B, 44 (107): 95-101.

Thatcher, V.E. 1991. Amazon Fish Parasites. Amazoniana 11 (3/4): 263-571.

Thatcher, V.E. 1995. Comparative pleopod morphology of eleven species of parasitic isopods from Brazilian Fish. Amazoniana 13 (3/4): 305-314.

Thatcher, V.E. 2000. The isopod parasites of South American
Fishes, p. 193-226. In: G. SAlgado-Maldonado; A.N. GarciaAldrete \& V.N. Vidal-Martinez (Eds). Metazoan parasites in the Neotropics. Mexico, Instituto de Biología, Universidad Nacional Autónoma de México, 310p.

Thatcher, V.E. 2002. The isopods of South American fishes. Boletim do Museu Paraense Emílio Goeldi 18 (2): 77-199. Thatcher, V.E. 2006. Amazon fish parasites. Sofia, Pensoft Publishers, 508p.

TRILlES, J.P. 1973. Notes documentaires sur les isopodes cymothodiens parasites de poissons d'eau douce de l'Amerique du Sur. Bulletin du Muséum National d'Histoire Naturelle, Serie Zoologie, 88: 239-272.

Submitted: 27.III.2008; Accepted: 24.I.2009.

Editorial responsibility: Marcus Vinicius Domingues 